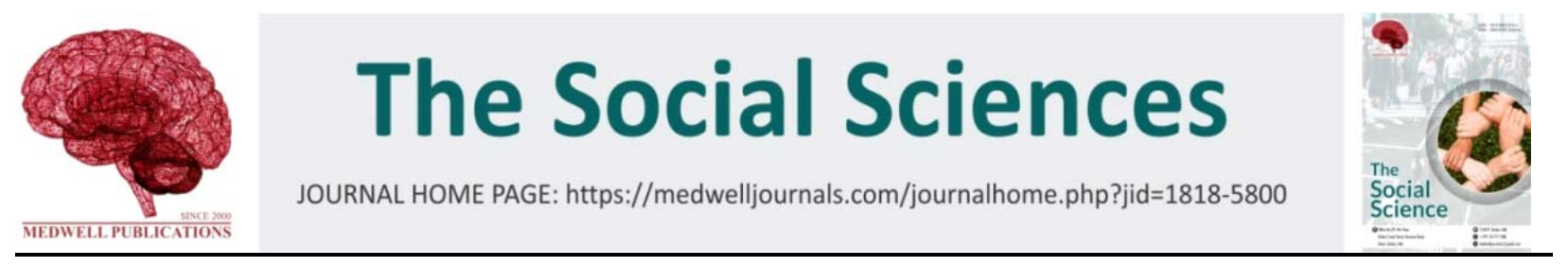

\title{
The Capacity to Think Critical Students to the Matter Environmental Management with the Approach Skill the Process of Science Junior High School (SMPN) 14 Ambon
}

\author{
${ }^{1}$ Muhammad Rijal, ${ }^{1}$ Idrus Sere, ${ }^{1}$ Janaba Renngiwur and ${ }^{2}$ Haryati Sutia \\ ${ }^{1}$ Religious Institute State Islamic Ambon, Ambon, Indonesia \\ ${ }^{2}$ Teacher Junior High School Kendari, Kendari, Indonesia
}

Key words: STAD, KPS, CTL, activity, the ability to think critically, Ambon

\section{Correspoding Author:}

Muhammad Rijal

Religious Institute State Islamic Ambon, Ambon, Indonesia

Page No: $15-19$

Volume 15: Issue 1, 2020

The Social Science

ISSN (P): 1818:5800

Copy Right: (C) Medwell Publications
Abstract: Data analyzed a sort of descriptive set and inferential (using statistic test independent sample t-test with the program SPSS 20), the first significance hypothesis used $\alpha=0.05$. The research results show activity learn model STAD with the approach KPS be in the active; activity learn model STAD with the approach CTL be in the quite active; capability of think critically model STAD with the approach KPS be in the high; capability of think critically model STAD with the approach CTL in the being; there is a difference in significant activity learn model STAD with the approach KPS and models STAD with the approach CTL and there is a difference in the capacity think critically model STAD with the approach KPS and models STAD with the approach CTL students in SMPN 14 Ambon.

\section{INTRODUCTION}

Backgound: The learning process, most educator only riveted on textbook as the only source of teaching and learning (Nama and Ahmatd, 1997). This is what into feebleness in learning science is a problems technique assessment learning inaccurate and thorough. The evaluation process that is carried out during this is only emphasis on mastery concept were seized by a test written objective and subjective as a measuring instrument. By means of this judgment, means tests carried out by new teacher measuring mastery of damage and that covers only domain cognitive a low level. The state of like it is a one indication to a weakness their experiences in the school.

The results of interviews with teachers science in SMP 14 Ambon and observations in learning which indicates that skill the process of students still less and student average get value under KKM $=71$ determined school. Students have not been able to find your own the concept of biology that learned, the learning process that uses the discussion method where there is students who dominated in his group to the process learning. Learning discussion on students cause knowledge uneven because there are several students just loosen up in clusters and the questions evaluation received did not oriented to develop the ability of think critically. This has resulted in the low the capacity to think critically students. Due to this students hard analyzes information of which there are inclined to accept the information that was delivered and that is written in the book and passive in asking questions and answer the question of the problem that was submitted by teachers and suggested the idea or the notion of the resolution of problems (Jackson, 2005).

According to Nurhayati, if a teacher teaches the fact only without regard to the process of how the fact is revealed then the fact of being taught's not entirely can be understood by students. Even students can assume that science was merely a reams of information. To be able to understand a fact or the concept of usually the student need to work with the objects that concrete do about, manipulation of the idea in order to obtain the data, it is more than just memorization. For it in their experiences science need to approach the process. The approach of the 
process in droves science is based on observations on what has been exercised by expert. The processes that elaborated from the activities of what has been exercised by expert it was so called skill the process.

According to Oemar (1994), is 5 species of the ability to develop through learning based on approach basic skills the process, namely observe done by the use of a senses such as the eye to collect the data relevant information with the interests of of learning, sehinggga study results can increase; interpret (inference) have skills interpret the fact, data information or events this skill required to do an experiment or research simple; predicted (prediction), capable of having skill link the data, the facts and information, students are required skilled anticsainste predicted an activity or event that might happen to events to come; classify to be skillful know differences and similarities for the result of surveillance of an object and held a classifications based on special features, the purpose or certain interest, making classifications need conscientiousness in observation; ask or communicating, students must be able to questioned concerning not understandable and convey systematically good the process as well study results to other students.

STAD (Student Achievement Teams Divisions) is one approach in learning cooperative the simplest, developed by Robert Slavin at the university of John Hopkin and constitute a a good for teachers new cooperative apply learning model in classes and cooperative type STAD has been widely used as in math, art, language, social and sciences. Learning cooperative type STAD divided into five main components: presentation class (class presentations), study group (teams), quiz (quizzes), increased score individual (improvement scores) and awards group (team recognition).

Approach contextual having the in philosophy learn the contruktivism. Contruktivism stressed that studying not only function as memorization but students to construction knowledge on his mind. Knowledge not can transversely into facts or a proposition that separate but reflect skill to be applied. It means, pragmatic approach contextual. According to Depdiknas, learning science should be implemented to grow the capacity to think, research and be scientific and communicate as important aspect skill life. Hence, learning science in junior high school stressed in the provision of learning experience CTL through the use of and of skills processes and scientific attitude. Skill process in self students can be developed approach in skill the process of science.

The results of previous studies show that the approach skill the process. Concluded that the approach KPS in learning matter environmental management impact on increase the capacity to think critical students. Based on the background problems that science above the purpose of research is as follows: to know activity learn through learning model STAD with the approach skill the process of science and students in SMP 14 Ambon, to know activity learn through learning model STAD with the approach contextual students in SMP 14 Ambon, to know the capacity to think critical through learning model STAD with the approach skill the process of science and students in SMP 14 Ambon, to know the capacity to think critical through learning model STAD with the approach contextual students in SMP 14 Ambon, to know the difference activity learn through learning model STAD with the approach skill the process of science and through learning model STAD with the approach contextual students in SMP 14 Ambon and to know a difference in the capacity think critically through learning model STAD with the approach skill the process of science and through learning model STAD with the approach contextual students in SMP 14 Ambon.

\section{MATERIALS AND METHODS}

The kind of research this is quasi experimental design with nonequivalent control group design. Population in this study were those coming vii the first half of the class are fulfilled SMP 14 Ambon the academic year 2015/2016 which consisted of six class. The sample collection techniques should be conducted by random. The population in class vii as many as 193 students. Class that referred to vila with 33 students learn model STAD with the approach (KPS) as a group and VII-b experiment with the number of 30 students learn model STAD with CTL approach as a class control. Data collection activity when the process of learning and the capacity to think critically and after a learning process. Data analyzed in descriptive and inferential (using statistic independent sample test t-test program SPSS with 20), level of significance on hypothesis used $\alpha=0.05$.

\section{RESULTS AND DISCUSSION}

Data based on the results of the activity of learning through learning model STAD skill with the approach of the process of science students in junior 14 Ambon obtained data in Table 1.

The distribution of the percentage of the frequency of data learning activities through STAD kind of classroom skills with the approach the process of science can be seen in Table 2.

Table 2 the data can indicate that most students class experiment through learning model STAD with the approach skill the process of science class VII-a in SMP 14 Ambon considered active Table 3.

The distribution of data activity through the percentage of learning learning STAD by approach contextual seen in Table 4.

Based on the Table 4 has indicated that most students control through learning model STAD by approach contextual class VII-b secondary schools 14 Ambon are very active (Table 5). 
The Soc. Sci., 15 (1): 15-19, 2020

Table 1: The results of the analysis descriptive activity learn class experiment

\begin{tabular}{lc}
\hline Statistic & Value activity \\
\hline Sample & 33 \\
Mean & 6.94 \\
Median & 7.00 \\
SD & 1.56 \\
Variance & 2.43 \\
Highest value & 9.00 \\
Lowest value & 3.00 \\
\hline
\end{tabular}

Table 2: Frequency, distribution data activity learn class experiment

\begin{tabular}{llcc}
\hline Interval & Category & Frequency & Percentage \\
\hline $8-9$ & Very active & 12 & 36 \\
$6-7$ & Active & 16 & 48 \\
$4-5$ & Active quite & 4 & 12 \\
$2-3$ & Active less & 1 & 3 \\
$0-1$ & Inactive & 0 & 0 \\
Amount & & 33 & 100 \\
\hline
\end{tabular}

Table 3: The results of the analysis descriptive activity learn class

\begin{tabular}{lc}
\multicolumn{2}{c}{ control } \\
\hline Statistic & Value activity \\
\hline Sample & 30 \\
Mean & 5.93 \\
Median & 6.00 \\
SD & 1.87 \\
Variance & 3.51 \\
Highest value & 9.00 \\
Lowest value & 2.00 \\
\hline
\end{tabular}

Table 4: Frequency, distribution data activity learn class control

\begin{tabular}{llcc}
\hline Interval & Category & Frequency & Percentage \\
\hline $8-9$ & Very active & 7 & 23 \\
$6-7$ & Active & 10 & 33 \\
$4-5$ & Active quite & 11 & 37 \\
$2-3$ & Active less & 2 & 7 \\
$0-1$ & Inactive & 0 & 0 \\
Amount & & 30 & 100 \\
\hline
\end{tabular}

Table 5: The analysis descriptive ability to think critically learn class experiment

\begin{tabular}{lc}
\hline Statistic & Ability critical thinking \\
\hline Sample & 33 \\
Mean & 73.92 \\
Median & 71.43 \\
SD & 14.95 \\
Variance & 223.62 \\
Highest value & 96.43 \\
Lowest value & 46.43 \\
\hline
\end{tabular}

Table 6: Distribution data ability to think critically learn class experiment

\begin{tabular}{llcc}
\hline Interval & Category & Frequency & Percentage \\
\hline $81-100$ & Very active & 11 & 33 \\
$61-80$ & Active & 15 & 45 \\
$41-60$ & Active quite & 7 & 21 \\
$21-40$ & Active less & 0 & 0 \\
$0-20$ & Inactive & 0 & 0 \\
Amount & & 33 & 100 \\
\hline
\end{tabular}

Distribution data the percentage and frequency the capacity to think critical learn s through STAD with the approach skill the process of science can be seen in Table 6.
Table 7: The analysis descriptive ability to think critically learn class control

\begin{tabular}{lc}
\hline Statistic & Ability critical thinking \\
\hline Sample & 30 \\
Mean & 63.69 \\
Median & 62.50 \\
SD & 11.87 \\
Variance & 140.81 \\
Highest value & 85.71 \\
Lowest value & 39.39 \\
\hline
\end{tabular}

Table 8: Distribution data ability to think critically learn class control

\begin{tabular}{llcc}
\hline Interval score & Category & Frequency & Percentage \\
\hline $81-100$ & Very active & 2 & 7 \\
$61-80$ & Active & 13 & 43 \\
$41-60$ & Active quite & 14 & 47 \\
$21-40$ & Active less & 1 & 3 \\
$0-20$ & Inactive & 0 & 0 \\
Amount & & 30 & 100 \\
\hline
\end{tabular}

Based on the Table 6 it can be indicate that most students class experiment through learning model STAD with the approach skill the process of science public SMP students 14 Ambon class VII-a the capacity to think critical category high (Table 7).

The percentage of the distribution of data and frequency ability think critically learn through learning STAD model with contextual approach can be seen in Table 8 .

Based on the Table 8 it can be indicate that most students control through learning model STAD by approach contextual graders viib secondary schools 14 Ambon has the ability to think critically is at medium category.

The results of data activity over learning STAD with the approach skill the process of science class experiment. student category active. Vision said, activity or activity lab work memengang perana important in teaching science because they give the scientific method to students. Students trained reading data objectively and draw conclusions of an activity lab work when it has many the fact that supports it. Students are required to realize limited measurements in research and understand meaning a theory. Of discussion result above can be drawn indicate that $\mathrm{s}$ through STAD with the approach skill the process of science class experiment the percentage students are in the active. Indicates that learning s through STAD with the approach skill the process of science class experiment is considered very effective, since, the activity fulfilled.

Through learning STAD the class control contextual the percentage of students are in the active. Signaling that learning through learning STAD by approach contextual control class is considered effective since the activity met. Nasution in Nugroho, said the principle of activity is important in learning he taught himself activity without activity impossible someone studying. All knowledge can be obtained through the observation and experience. 
Test scores ability to think critically students who given after learning through STAD the process class skills science experiments. The ability to think critically students identified five major aspects as an indicator in think critically namely formulate problems, giving argument do induction, evaluate and take decisions and actions. Based on the research done, the ability to think critically junior high school students in 14 Ambon be in the high. This is supported by opinion Rustaman in Noviyanti skill observe that is the most basic skills in the process of obtaining science and is important to develop skill process of another. Observation is responding to various objects and events the Earth and use panca the senses, so that, students capable of to study matter environmental management. Formulate problems, give argument do induction, evaluate and make the decision and the act of the activities is the capacity to think critical. Santoso for 2010, stated that s through by adopting KPS in the class experiments on research this is a group. The formation of groups is aimed the students can afford to build of knowledge in together. Through work group enables the student can reveal the idea, listen to opinion friend, contributing ideas and training communication with the other. So that, it can be get students to think critically (Idowu et al., 2003).

Curtodan in (2005), Noviyanti in (2014) said that think critically can be developed by enriching experience students meaningful, the experience can be a chance argues verbally and writing like a scientist. Approach skill process of science give the occasion to students do learning it scientist, so will increase the ability to think critically students could to the matter environmental management. There is a difference in the activity of students at both learning the approach. Skills to approach the lab work will be attract attention students by comparison with only observation picture is in LKPD contained in class control.

Excess the application of model STAD oriented on the approach of skill the process of science were students trying to find knowledge own with skill the process owned and train students implement lab work as practiced by the scientists, so that, students able to work and discuss group and increasing the activity of students because learning centered on students. Based on the results of the analysis inferential by using the independent sample t-test show there is a difference in significantly on the ability of think critically students who through learning model STAD with the approach approach skill the process of science and through model learner an STAD with the approach contextual students in SMP 14 Ambon.

Skill approach the process of being applied to the learning capable of developing ability owned and emphasized how learning find prescience own and manage acquisition. By finding the concept of independently then students more easily understand the concept of the findings of others. In discovering the concept own students trained using his ability to investigate systematically and critically, so, the students to formulate knowledge acquired. According to Haryono, skill in the process of the view that every student have the potential to different and in normal circumstances they can advance potential optimally. Hence, the teachers are providing facilities to students with creates an enabling environment that all students could be optimized. In line with the opinions of the approach skill process will be make the most of think critically students compared with contextual approach.

Second approach able to increase the capacity to think critical in line with research conducted by Syahbana approach contextual teaching learning improve the ability think critically mathematics. And the results of research conducted Noviyanti, concluded that the approach skill the process of science impact on think critically school tuition to the matter ecosystem (Sadiman, 2001). But from the results the capacity to think critical school tuition in junior high schools 14 Ambon the difference between class experiment and class control. On class experiment attention school tuition at the more attention to supervise the lab work.

\section{CONCLUSION}

Based on the research results show the activity of learning model STAD with the approach KPS be in the active, the activity of learning model STAD with the approach CTL be in the quite active, the ability of think critically model STAD with the approach KPS be in the high, the ability of think critically model STAD with the approach CTL in medium category, there is a significant difference activity learn model STAD with the approach KPS and models STAD with the approach CTL and there is a difference in the capacity think critically model STAD with the approach KPS and models STAD with the approach CTL students in SMP 14 Ambon.

\section{SUGGESTIONS}

Based on research results obtained, suggested some advice to improve the ability to think critically students in their experiences as follows: expected to the teacher science which apply approach skill process of preparing the materials to be used in learning lab work, so, the time to start as planned, expected in their approach contextual matter adjusted with matter learning, should to learning 
all preparations start of a device need preparation is good that the purpose of learning could be achieved, the sample research is used a student VII SMP 14 Ambon. The authors argue when similar research is done at different sample, so, the result that obtained may well be different. This is a morbid occurred because the characteristics of students each school is also different, so that, the result of this research has not been able to universally for a sample of different there should be further research skills as for approaching the process of science on which materials science another and to the teacher science subjects is expected to apply kind of classroom STAD with the approach KPS to increase the activity and the capacity to think critically students on any material environmental management.

\section{REFERENCES}

Idowu, B., E. Ogunbodede and B. Idowu, 2003. Information and communication technology in Nigeria the health sector experience. J. Inform. Technol. Impact, 3: 69-76.

Jackson, M., 2005. The impact of ICT on the development of information literacy. J. E. Literacy, 2: 15-26.

Nama, S. and R. Ahmatd, 1997. [Multimedia Learning]. Sinar Baru Publisher, Bandung, Indonesia, (In Indonesian)

Oemar, H., 1994. Multimedia Guruan. P.T. Citra Aditya Bakti, Bandung, Indonesia,.

Sadiman, A.M., 2001. [Interaction and Teaching Motivation Motivation]. Raja Grafindo Persada, Jakarta, Indonesia, ISBN: 9789794210512, Pages: 224 (In Indonesian). 